\title{
Loose Smut of Wheat (Ustilago tritici) and Its Managements: A Review Article
}

\author{
Arif Abrahim \\ Department of Horticulture and Plant Science, College of Agriculture and Veterinary Medicine, Jimma \\ University, P.O. Box. 307, Jimma Ethiopia
}

\begin{abstract}
Among all diseases of wheat, seed-borne diseases such as smuts and bunts are found in every area where the wheat is grown. It is one of quarantine diseases of wheat that reduces the quality of grain seeds. Loose smut of wheat is occurred in cool and moist climate conditions. The successful infection of loose smut can occur after the anthesis. The pathogen remains dormant in the mature seed and germinates with germinating seeds. The mycelium of the fungus grows in the crown node and finally invades the inflorescence tissues. It develops with the seed embryo. It is disseminated by infected seeds and air by short distance. The pathogen has different types of host range especially all species of triticum. It is also pathogenic on Aegilops and rye (secale cereal). Most of the inoculums sources of loose smut are infected wheat seeds and air borne teliospores from smutted heads. In every infected areas of wheat by loose smut, a new race may arise by recombination of pre-existing virulence genes or through mutations. So, different types of management systems such as using of certified seeds treated with protectant fungicides, planting of resistant cultivars is very important.
\end{abstract}

Keywords: Wheat seeds, Loose smut, Ustilago tritici, seed-borne diseases

DOI: $10.7176 / \mathrm{JBAH} / 9-8-05$

Publication date: April $30^{\text {th }} 2019$

\section{Introduction}

Seed-borne diseases were the first diseases studied scientifically among all diseases of wheat by Tillet in 1755 (Agrios, 2005). Several wheat diseases are spread inthe world and the most devastating pathogenic forms for wheat are various types of fungi (reviewed in Zillinsky, 1983). Fungi are the main pathogenic organisms which causing seed-bornediseases of cereals (reviewed in Richardson, 1996). Out of the fungi caused seed-borne diseases ofwheat, smuts and bunts are found in every wheat growing regions of the world (reviewed in Wilcoxson \& Saari, 1996; Matanguihan et al., 2011; Knox \& Menzies, 2012). There are five smut and bunt diseases inwheat such as loose smut, flag smut, common bunt, Karnal bunt and dwarf bunt of wheat (reviewed in Wilcoxson \& Saari,1996). Other fungi caused seed-borne diseases of wheat are black point or smudge kernel, scab, tan spot and ergot (Mathur \& Cunfer, 1993).

Loose smut (Ustilago tritici) of wheat is occurred by a cool and moist climate conditions during anthesis. Losses can be significant in regions with such favorable climatic conditions, although losses have also been reported in dry and warm regions. The optimum time for infection is between early and mid anthesis, but successful infection can occur even after anthesis. Even if, losses caused by loose smut infestation are not devastating, it can cause moderate economic losses, resulting in profit reductions of 5-20\% at an infection level of 1-2\% (reviewed in Wilcoxon and Saari, 1996). The pathogen remains dormant in the mature seed at the growing point. After seed germination, the mycelium grows in the crown node and later invades inflorescence tissues. This allows the fungus to be transported into the developing spike, where it sporulates, and disperses teliospores at spike emergence (Murray et al., 2009).Several methods are currently available to control loose smut; in many parts of the world, the use of resistant wheat cultivars, certified seed and fungicide seed treatments is highly effective in controlling loose smut of wheat. However, most of the resistant wheat cultivars detected to have a narrow resistance spectrum and seed treatment is either not used or can have limited efficacy (reviewed in Wilcoxon and Saari, 1996).

The fungus (Ustilago tritici) in wheat normally hibernates as mycelium within the wheat seed, vegetates systemically, and sporulates in the young wheat heads previous to their emergence, destroying most of the tissues of the spike, except the rachis, and producing a black powdery mass of smut spores in their stead. Smutted and healthy heads emerge during approximately the same period, and spores from the former are disseminated through the air while the healthy heads are in bloom. Inoculation occurs through the chance falling of one or more spores on the ovary or stigma, which is exposed through the opening of the glumes in the process of blooming. Within a few days all the spores are blown or washed from the diseased heads, and only the naked rachises of the spikes persist. Following their inclusion within the glumes of the healthy heads, the spores soon germinate. The germ tubes eventually enter the developing kernel and produce a mycelium, which hibernates within the matured kernel, thus completing the life cycle. Therefore, this article was reviewed based on knowing of pathogen about their general characteristics such as: infection and dissemination mechanisms, its complete life cycle, variation in genetic makeup or variability and control measures. 


\section{Importance and Distributionof Loose Smut}

Seed holds the largest share of plant propagation material moving to international trade and therefore seed is considered one common route for the spreading of destructive plant diseases

(Neergaard, 1986). When one or more of the phases of the life cycle of a disease is being connected with the seed, the diseases are defined as "Seed-borne diseases" (Pearce, 1998). Loose smut is a cereal disease present around the world (Agrios, 2005). It was known by man already during the historic time. Thus, Roman people recognized the disease and designated it Ustilago, meaning burn in Latin (Wilcoxson \& Saari, 1996). The disease can cause both yield and quality reduction of wheat. Smuts along with the rusts were the main concern of farmers until the 20th century in most of the wheat growing areas (Agrios, 2005).Loose smut is mainly spread by infected seed; it can also be spread by air, but not for long distance (Nielsen \& Thomas, 1996). The loose smut disease is internally seed-borne, i.e. the spores remain in the seed embryo, and thereafter in a presence of favorable conditions it affects the new plant from the same infected seed (Pett et al., 2006). The disease is usually seen at higher elevations, and wet and cool weather is favourable for the disease (Saari et al., 1996).

Loose smut [Ustilago tritici (Persoon) Rostrup] of wheat occurs wherever cultivated wheat, Triticum aestivum and T. turgidum, is grown (Anon. 1982). Since the pathogen is seedborne, itwill be spread from place to place by man; rarely is it disseminated over long distances through the air. U. tritici did not occur in the Americas, Australia, or South Africa before European settlers introduced it when they brought wheat seed with them. Loose Smut is never devastating, but causes low to moderate annual losses. It is more common in regions with a cool, moist climate during flowering of the host. Yet, even in dry warm climates, economic losses occur. Since percentage infection equals loss in yield, and since most of the monetary return from any one field goes into cost of production, even 1-2\%infection can reduce profit to the farmer by $5-20 \%$.

\section{Symptoms of loose smut}

Loose smut is easily recognized at ear emergence as individual grains are completely replaced by a mass of black fungal spores (Figure 1 below). Partly affected ears are sometimes seen. The spores are released as soon as the ear emerges, leaving only the bare remains of the ear rachis. Because the blackened ears are so obvious in the crop at ear emergence the disease appears to be very severe, even at very low incidence. The fungus is carried passively up with the plant growing point, which eventually develops into a smutted ear (reviewed in Malik and Batts, 1960). Neither the infected seed nor the developing plants show any obvious or unambiguous macroscopic symptoms until appearance of infected ears (P. Eibel et al., 2005; R.H. Sammour, 1991 and R.H. Sammour, 1994).

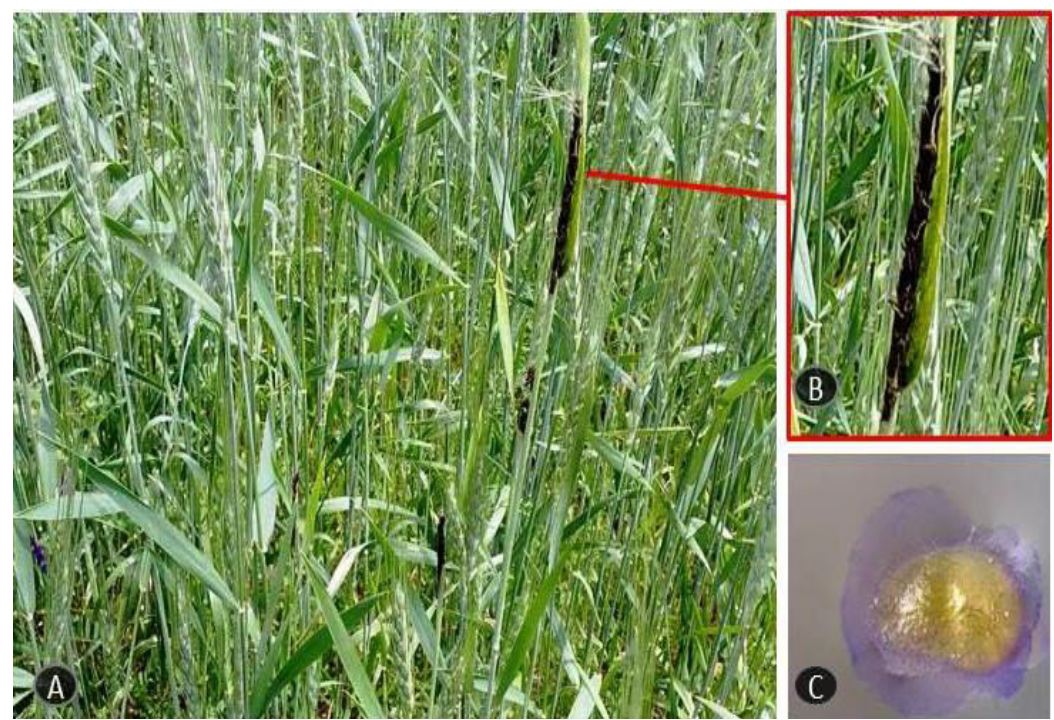

Figure 1. Wheat loose smut. A. Infected wheat field; B. Mass of spores replacing the spike; C. Infected embryo, where mycelllium is seen on the surface of scutellum.

\section{Host range of loose smut}

Wheat species are the principal hosts of $U$. tritic, $i$ which has been found on all Triticum spp. except $T$. timopheevi. Loose smut occurs on Aegilops spp. and is likely tohave parasitized Aegilops before cultivated wheat evolved. Some races that are specialized on bread or durum wheatsare pathogenic on some Aegilops spp., while most races on Aegilops spp. are not pathogenic on Triticum spp. (reviewed in Nielsen, 1985).

The Loose smut fungus is pathogenic on rye (Secale cereale L.) and economically significant on this crop (reviewed in Humphrey and Tapke, 1925). Races that specialize on either bread or durum wheat can attack rye, 
but the level of infection is low, and in rye resistance is more frequent than in wheat. Cultivars of triticale (X Triticosecale) can be susceptible to any race that attacks the parental wheat or rye (reviewed in Nielsen, 1973).In nature, $U$. tritici is rare on wild grasses other than Aegilops spp. There are two reports of natural occurrence on Agropyron spp. in North America, and one report each on Elymus and Taeniatherum spp. in Morocco (Nielsen 1978). U. tritici is also pathogenic on Haynaldia, Hordeum, and Secale spp. Within many of the wild species, there are both susceptible and resistant strains; specialization by the fungus is thus not restricted to cultivated wheat. Likewise, secondary symptoms, such as the incompatibility reaction of seedlings and shorter plants, are found within all host species.

Most wild hosts have no role in the epidemiology of wheat loose smut. The possible exceptions are races found on Aegilops spp., but only eight such races have been tested for virulence/avirulence on accessions of bread and durum wheat. Seven races were avirulent and one was virulent on certain bread and durum wheats (reviewed in Nielsen, 1985). The virulent race originated from T. tauschii (Ae. squarrosa) from an area of Iran where little wheat is grown. This supports the view of aphylogenetic relationship among races from $T$. tauschii and T. aestivum (reviewed in Krivchenko, 1984). Races on T. tauschii may harbor genes for virulence not yet found in races on T. aestivum. Likewise, races found on wild diploid and tetraploid relatives of T. turgidum may carry genes for virulence on durum wheat.

\section{The pathogen}

Loose smut of wheat is caused by the heterobasidiomycetous fungus Ustilago tritici (Persoon) Rostrup. It is the only Ustilago sp. that occurs on wheat. A trinomial system to designate strains that are specialized on certain host species is impractical because of the multitude of possible formae speciales and the overlapping pathogenicity of each strain on several host species or genera (reviewed in Nielsen, 1985). Because $U$. nuda, the cause of loose smut of barley, and $U$. tritici have identical spores and a similar biology, the two diseases have been claimed to be caused by the same organism. This taxonomic treatment, based solely on spore morphology, is untenable because it ignores the following important differences (as reviewed in Kellerman and Swingle, 1989, Kim et al., 1984, Kanehira and Shinohara, 1986, Vánky, 1994): The morphology of the promycelium and of the monokaryotic and dikaryotic hyphae after germination is different in the two fungi. In $U$. nuda, all monokaryotic haploid isolates of the MAT-2 mating type are proline auxotrophs, and those of the MAT-1 mating type are temperature sensitive; no such properties are found in the isolates of $U$. tritici. The sori of $U$. nuda are initially covered by a thin membrane when the infected spike emerges, whereas those of $U$. tritici are naked. There are pronounced differences in polypeptides and isozymes between the two species, suggesting genetic differences. But, these differences justify that $U . n u d a$ and $U$. tritici as related species and may have evolved from $U$. tritici (reviewed in Nielsen, 1987b).

\section{Inoculums' sources and life cycle of pathogen}

Loose smut is a seed borne disease. The fungus is carried systemically in the infected seed. When infected seed is sown the seed germinates and the fungus grows systemically within the seedling colonizing meristemic tissue. The mycelia reach maturity when spikes develop, producing smutted heads. At flowering, airborne teliospores from the smutted heads are spread by wind to healthy plants. Under mild temperatures and humid conditions, spores landing on florets are germinated. The spore's germ tube penetrates the ovary, developing a mycelium in the embryo. The mycelium remains dormant in the asymptomatic seed until the seed germinates (http://www.uky.edu/Ag/IPM/scoutinfo/wheat/disease/disl ist.htm).

Infection of wheat plants takes place shortly before, during, and two days after the flowering period. The maximum infection occurs during flowering. Wind, rain, insects, and other agents carry the olive black teliospores from a smutted head to the open flowers of a healthy head. Here, in the presence of moisture, with a temperature of $60^{\circ}$ to $71^{\circ} \mathrm{F}\left(16^{\circ}\right.$ to $\left.22^{\circ} \mathrm{C}\right)$, the spores quickly germinate and grow down the stigma and pistil-the female parts of the flower-to invade the young embryo (seed). Infection also may occur by direct penetration of the embryo wall. Within a week after flowering, the ovary and flower parts become resistant to infection. After establishing itself as mycelium in the embryo of the developing kernel, the loose smut fungus becomes dormant (https://ipm.illinoidiseases/rpds/112.pdfs.edu/).

When an infected kernel is sown and begins to sprout, the mycelium of the smut fungus again becomes active and grows systemically into the young shoots to the growing point. The fungus normally keeps pace with the development of the wheat plant. By heading time, the spikelets in an infected wheat head are completely transformed, except for a pericarp membrane, into a dusty mass of teliospores (Figure 2). The delicate gray membrane soon tears away as the head emerges to release the mass of dry spores, completing the disease cycle (https://ipm.illinoidiseases/rpds/112.pdfs.edu/). 


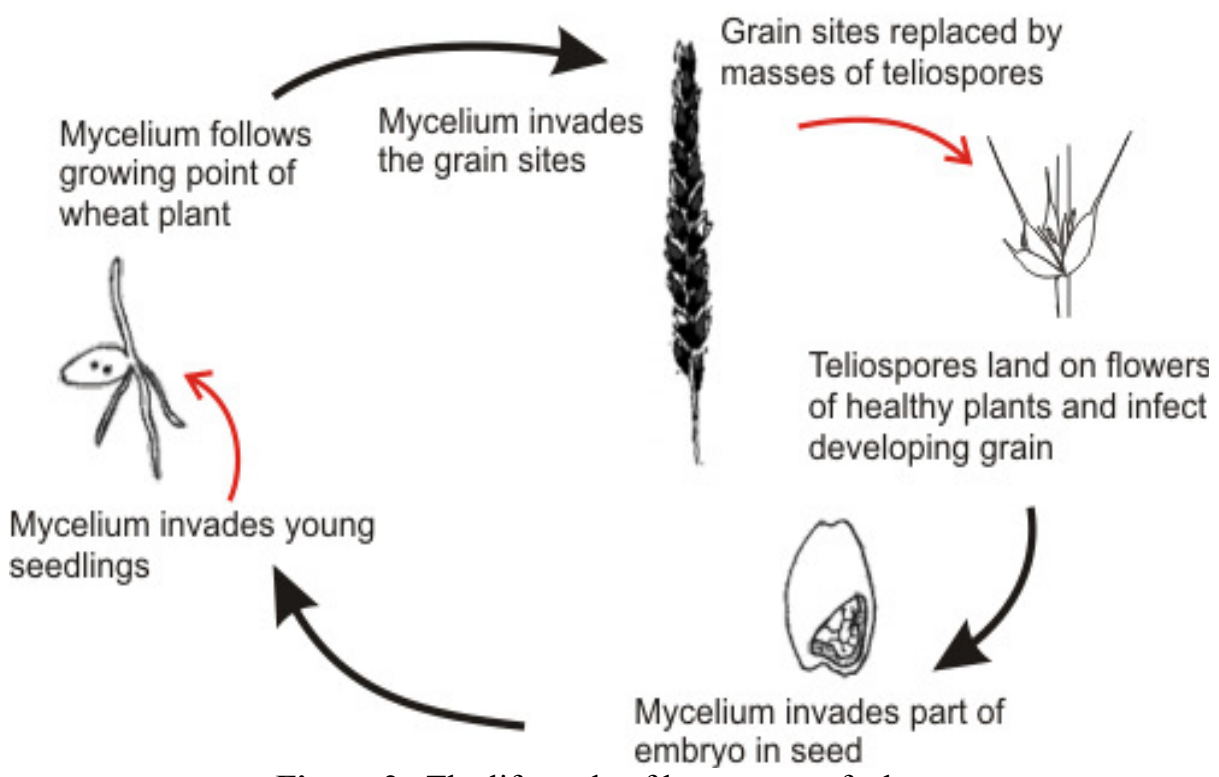

Figure 2. The life cycle of loose smut of wheat

\section{Infection mechanisms}

Infection by $U$. tritici occurs only on the ovary. Spores enter the floret, germinate, and form dikaryotic hyphae that infect the ovary, usually at the brush end (reviewed in Batts, 1955b, Shinohara, 1976). The process requires 5 to 7 days. Once in the testa, the hyphae grow intracellularly; but in the integument and nucellus, the fungus grows intercellularly, mainly on the dorsal side of the developing caryopsis. The mycelium enters the upper and side parts of the scutellum 10 to 15 days after penetration and grows through the hypocotyl into the plumular bud, or growing point, of the embryo (Figure 3). Thus, about 3 weeks are required for the fungus to reach the growing point, where it will lie dormant in the mature seed. Infected seeds do not differ outwardly from healthy seed.

Figure 3.Teliospores of $U$. tritici germinating to form curved promycelia in which meiosis takes place (400x). The resulting haploid hyphae will subsequently fuse to produce dikaryons (Adopted from Wilcoxson, and Saari, 1996).

When an infected seed germinates, the mycelium in the growing point is revitalized and carried in the crown node as the sub crown internodes elongates. The fungus permeates crown tissues and enters the initials of the inflorescence. As the developing spike is carried upward by elongation of the internodes, the mycelium is also carried upward and proliferates in the developing spike (Batts and Jeater 1958a). The dikaryotic nuclei fuse to form a diploid nucleus as the teliospores mature. At emergence of the spike, the teliospores are readily carried by the wind to nearby florets, where they germinate and cause infection, closing the life cycle of the fungus.

\section{Physiological Specialization of the Pathogen}

The study of races of Ustilago tritici had begun about1930 (Tiemann 1925, Piekenbrock 1927, Grevel 1930). Silva (195 1) noted possible differences in pathogen city within the population of loose smut in Brazil. Mascarenhas and Silva (1954), working with three samples of spores, collected from different state of Brazil and 
were found differences in pathogenicity between the pathogen inoculated on commercial cultivars. In other countries, physiologic races have been reported from Bulgaria (Mitov, 1958), France (Simon and Croisier, 1959), Great Britain (Batts, 1955; Doling and Hervey- Murray, 1966), The Netherlands (Oort,1944), Poland (Heinrich, 1973), Romania (Radulescu, 1935), USSR (Krivchenko,1970), India (Dastur, 1946), China (Wang, 1946), New Zealand (Cunningham, 1940),South Africa (Gorter, 1964), and USA (Bever,1953).In Canada, Hanna (1937) described four physiologic races of loose smut of wheat which he identified from three collections of spores originally made in 1929 from cultivars such as: Reward, Kota and Mindum. Later, Cherewick (1953) described 10 physiologic races that had been differentiated in Canada up to that time by using the same group of cultivars selected by Oort (1944) in the Netherlands.

A new race may arise by recombination of pre-existing virulence genes or by mutations at loci responsible for virulence. It is possible for new races to arise by recombination but this possibility is now greatly reduced because of wide spread use of the same cultivars and of pedigreed seed. Further, loose smut is a monocyclic disease that has only a limited number of infection sites are observed in any field. Therefore, the role of new races has been greatly overrated. Resistance of wheat to loose smut can be explained by existing races that escaped detection by race surveys that are necessarily restricted in geographic coverage and in the number of collections examined. A new race is recognized if teliospores from a single spike of a field collection give a pattern of virulence that differs from any known race in at least three consecutive tests on the differentials, or if it is virulent on a line or cultivar that has been resistant to all known races (Nielsen, 1983).

Several sets of differential cultivars have been used in different countries to test single gene differentials (reviewed in Tiemann,1925, Piekenbrock 1927, Grevel 1930,Oort 1947, Bever 1953), based on reactions of local cultivars to local collections of the pathogen.

\section{Detection of loose smut mycelia from wheat embryos}

Embryo test for detecting the dormant mycelia in the infected seeds has extensive importance to seed quality. As reported by Popp (1951) the infected portions of seeds were macerated in a solution of cotton blue lactophenol, in which the mycelia was stained blue. He described a detailed method for extracting and staining the mycelia of U. tritici using trypan blue. Morton (1960) described a quick method (i.e. 90 minutes) for determination of loose smut of barley embryo whole mounts. He used boiling solution of $5 \%$ sodiumhydroxide and $14 \%$ commercial liquid glass plus a small quantity of detergent in extraction. Boiling lactophenol served as clearing material and un-damaged embryos of high clarity were obtained. The mycelia of loose smut fungus $U$. nuda are redish brown and can be detected with dissecting microscope. Morton (1960) and Rennie (1990) extract embryos from seeds by soaking in $\mathrm{NaOH}$, clearing in boiling lactophenol and stained with trypan blue. Infected embryos can be identified under a dissecting microscope because of selective uptake of the stain by fungal hyphae. Bhutta and Ahmed (1991) detect 104 seeds samples of wheat by using the embryo count technique and tried to observe 15 seed samples with dormant mycelia of Ustilago tritici.

\section{Management of loose smut}

The best way to achieve a healthy crop, free of seed-borne diseases is to use healthy seed material of resistant varieties. The most effective measures of controlling the diseases and improving the crop are to breed resistant varieties and to carry out seed health status assessment (Agrios, 2005; Taylor et al., 2006). Chemical treatment of the seed and soil, hot water treatment and application of pesticides have shown good results as protection against seed-borne diseases (Agrios, 2005). Seed treatment is the method that has been suggested as the most effective management (reviewed in Buhariwalla et al., 2012). The use of certified seeds, free from the pathogen, is the most effective way of disease control. Other effective ways to control the disease are to use resistant varieties or to treat seeds with fungicides (Agarwal et al., 1993; Murray et al., 2009).

\section{Host Resistance}

Breeding of wheat varieties resistant to loose smut can help to manage the disease, however new varieties have to be tested against the races dominantly spread in the region of where these varieties are to be grown (Nielsen \& Thomas, 1996).

Several studies have been conducted to determine the inheritance of resistance to loose smut in hexaploid (common) wheat (R.E. Knox et al., 1990 and R. H. Sammour et al., 2007). Pandey and Gautam (1989) evaluated parental, F1, F2 and backcross generations from crosses between 7 varieties resistant to U. segetum var. tritici (HD2236, WL2087, WL2053, WL1804, WL1798, WL1567 and WL1541) and 2 susceptible varieties (Sonalika and WL711) for loose smut disease after inoculation at mid-anthesis with a dry spore mixture of field races. Segregation ratios indicated that resistance to $U$. tritici in each of the resistant varieties is controlled by a single dominant gene.

According to Nielsen and Thomas (1996), they summarized conclusions from many previous studies on resistant genes to loose smut as: (1) Genes can be partially or completely resistant and its resistance can be either 
dominant or recessive; (2) Resistance genes can stop the growth of the pathogen at one or more sites, e.g. in the ovary, embryo or seedling; (3) Although the embryo is genetically susceptible, the penetration of the fungi can sometimes be blocked by resistant maternal tissue of the ovary.

\section{Chemical control}

The first chemicals employed, as systemic fungicidal activity towards the loose smut fungi, were carboxins $(1,4-$ oxathiin derivatives) (Von Schmeling and Kulka, 1966), marketed as 'Vitavax' and 'Plantvax' (Edgington et al., 1966). The success of carboxins against loose smut led to the introduction of several carboxamide seed dressings including fenfuram ( Martin and Edgington, 1980).

Since the late 1970s, a number of broad-spectrum systemic fungicides, including the triazoles triadimenol, flutriafol and tebuconazole, have been introduced as seed treatments for cereal diseases like loose smut. The carboxins proved to be effective in eliminating loose smut infections when applied to growing plants as foliar sprays (Von Schmeling and Kulka,1966). Several of the active ingredients used in broad-spectrum seed fungicides, including flutriafol and tebuconazole, are also widely used in cereal crop sprays to control major foliar diseases such as powdery mildews and rusts. Triadimenol (the active ingredient of 'Baytan' used to control loose smut in seed) is the alcohol of triadimefon, a foliar fungicide widely used on cereals in the 1980s, though now replaced by newer fungicides (including other triazoles).

\section{Biological Control}

According to (Dharam and Maheshwarl, 1998), loose smut of wheat caused by Ustilago segetum var. tritici was controlled almost completely through seed treatment with any of the bioagents like Trichoderma viride, T. harzianum; Pseudomonas fluorescence and Gliocladiumvirens in combination with vitavax@0.125\% Concentration (Table 1).

The fungal and bacterial antagonists as Trichoderma. Gliocladium and Bacillus have been tried in the control of seed and soil-borne pathogens like Sclerotium rolfsii, Rhizoctonia solani, Macrophomina phaseolina and Sclerotinia sclerotiorum in the crops like chickpea, lentil, groundnut, mungbean, sesamum and french bean as described by Sharma et al. (1999), Mukhopadhyay, et.al. (1992), Raguchander et al. (1997), Sankar and Jeyarajan (1996), Abrahm Mathew and Gupta (1998); and Kehri and Chandra (1991).

Table 1. Effect of bio agents on per cent loose smut infection and field seedling emergence

\begin{tabular}{|c|c|c|c|c|c|c|c|c|c|c|}
\hline \multirow[t]{2}{*}{ Treatments } & \multirow{2}{*}{$\begin{array}{l}\text { Seed } \\
\text { treatment/ } \\
\text { soaking }\end{array}$} & \multirow{2}{*}{$\begin{array}{c}\text { Dose } \\
(\%)\end{array}$} & \multicolumn{3}{|c|}{ Percent infection } & \multirow[t]{2}{*}{ Mean } & \multicolumn{3}{|c|}{ Per cent Emergence during } & \multirow[t]{2}{*}{ Mean } \\
\hline & & & $1996-97$ & $97-98$ & $98-99$ & & $1996-97$ & $97-98$ & $98-99$ & \\
\hline Trichoderma viride & Slurry & 0.4 & 6.13 & 9.94 & 2.14 & 6.06 & 25.82 & 33.09 & 42.64 & 33.85 \\
\hline Trichoderma harziamum & Slurry & 0.4 & 5.54 & 11.19 & 1.38 & 6.03 & 23.75 & 40.11 & 41.00 & 34.95 \\
\hline Pseudomonas fluorescence & $6 \mathrm{~h}$ soaking & 4.0 & 7.79 & 18.28 & 3.74 & 9.93 & $33-98$ & 50.83 & 50.27 & 45.00 \\
\hline Vitavax & Dry & 0.125 & 0.85 & 3.53 & 1.23 & 1.87 & 25.74 & 57.97 & 51.12 & 44.94 \\
\hline Trichoderma viride + vitavax & Slurry+ dry & $0.3+0.125$ & 1.03 & 0.07 & 0.80 & 0.63 & 37.25 & 41.03 & 40.76 & 39.68 \\
\hline $\begin{array}{l}\text { Trichoderma harzianum }+ \\
\text { vitavax }\end{array}$ & Slurry+ dry & $0.3+0.125$ & 1.85 & 0.02 & 0.38 & 0.75 & 27.63 & 38.62 & 46.12 & 37.45 \\
\hline $\begin{array}{l}\text { Pseudomonas fluorescence }+ \\
\text { Vitavax }\end{array}$ & $6 \mathrm{~h}$ soaking & $4.0+0.125$ & 0.27 & 0.28 & 0.83 & 0.46 & 32.93 & 52.27 & 50.46 & 44.22 \\
\hline Gliocladium virens & $12 \mathrm{~h}$ soaking & $10^{6}$ spore $\mathrm{ml}^{-1}$ & 8.13 & 17.69 & 2.81 & 9.54 & 35.74 & 49.39 & 49.95 & 43.69 \\
\hline G.virens + vitavax & $\begin{array}{l}12 \text { h soaking } \\
+ \text { dry }\end{array}$ & $\begin{array}{l}10^{6} \text { spore } \mathrm{ml}^{-1} \\
+0.125\end{array}$ & NT & 0.15 & 0.33 & 0.24 & NT & 38.37 & 48.14 & 43.42 \\
\hline Water soaking & $24 \mathrm{~h}$ & - & 7.74 & 16.92 & 1.97 & 8.87 & 40.84 & 47.48 & 49.89 & 46.07 \\
\hline Nimbecidine & Dry & 0.5 & 5.03 & 14.98 & 1.81 & 7.27 & 24.81 & 46.48 & 44.56 & 38.62 \\
\hline Vitavax & Dry & 0.25 & $0.25^{a}$ & 1.58 & 0.73 & 0.85 & 28.04 & 47.94 & 44.60 & 40.19 \\
\hline Untreated control & & - & 5.20 & 16.37 & 3.18 & 8.25 & 25.89 & 49.60 & 41.34 & 38.94 \\
\hline $\mathrm{CD}$ at $5 \%$ & & & 2.11 & 3.54 & 1.09 & & 8.70 & 7.05 & 5.72 & \\
\hline $\begin{array}{l}\text { Loose smut infection based on } \\
\text { embryo count method }\end{array}$ & & & 4.25 & 19.57 & 4.19 & & & & & \\
\hline
\end{tabular}

NT: Not Tested

(Adopted from Dharam Singh and V.K. Maheshwarl, 1998)

\section{Conclusions and Prospects}

Ustilago tritici is an obligate parasite that hampering wheat production in all over the world. The fungi survives on wheat crop like a dormant fungal line within the embryo associated with wheat seeds. The disease causing pathogen is activated once due to contaminated seeds germinates; also it extends toward the actual growing stage from the crop plant. Apparently from blooming onwards once the plant starts form heads, the loose smut fungi invade all the younger head cells and tissues. As far as future directives are concerned for loose smut 
management, further surveys need to be conducted to assess the significance of the disease throughout the agroecology. It is also desirable to search for loose smut resistance by testing many more wheat germplasms and to test the efficacies of several seed treatment fungicides for the purpose of development of integrated loose smut management options for sustainable wheat production.

\section{References}

Abrahm Mathew, K and Gupta, S.K (1998). Biological control of root rot of french bean caused by Rhizoctoniasolani. J Myco. PI. Pathol. 28: 202-205.

Agarwal, V.K., Chahal, S.S. \& Mathur, S.B. (1993). Loose smut (Ustilago tritici). In: Mathur, S.B. \& Cunfer, B.M. (Eds.) Seedborne Diseases and Seed Health Testing of Wheat. pp. 59-67 Institute of Seed Pathology for Developing Countries. Danish Government. ABC Grafik. Frederiksberg, Denmark.

Agrios, G.N. (2005). Plant Pathology. Fifth Edition. ed. London: Elsevier Academic Press.

Anon. 1982. Ustilago nuda (Jens.) Rostr. Map No. 368. Disribution Maps of Plant Diseases. Common wealth Mycological Institute, Surrey, England.

Batts, C.C.V. 1955a. Loose smut (Ustilago tritici (Pers.) Rostr.) of wheat: physiologicalspecialization and reaction of varieties in England.Ann. Appl. Biol. 43:533-537.

Batts, C.C.V., and A. Jeater. 1958a. The development of loose smut (Ustilago tritici) in susceptible varieties of wheat, and some observations on field infection. Trans. Brit. Mycol.

Bever, W.M. 1953. Further studies on physiologic races of Ustilago tritici. Phytopathology 43:681-683.

Bhutta, A.R., and S.I. Ahmed; 1991. Pakistan J. of Phytopathology, 3, 7-11.

Buhariwalla, H.K., Duveiller, E. \& Kosina, P. Common and dwarf bunt (Extended information from Wheat Doctor, CIMMYT). [online] Available from: http://wheatdoctor.cimmyt.org/index.php/en/component/content/article/172/138-common-and-dwarf-buntextended-information. [Accessed 02/11/2012].

Cherewick, W.J. 1953. Smut diseases of cultivated plants in Canada. Can. Dept. Agric., Ottawa, Publ. 887. 58 pp.

D.J. Morton; 1960. Phytopathology, 50, 270- 272.

D.K.Pandey, P.L.Gautam; 1989. Plant Disease Research, 4, 167-169.

DASTUR, J. F. 1946. Pages 66-72 in Report of the Imperial Mycologist. Sci. Rep. Agric. Res. Inst. New Delhi. 1944-1945. (Abstr. in Rev. Appl. Mycol. 26:44-45. 1948.)

DHARAM SIGHN and V.K. MAHESHWARl, 1998. Biological seed treatment for the control of loose smut of wheat. Indian Agricultural Research Institute. Regional Station. Karnal 132002.

Doling, D. A. and Hervey-Murray, C. G. 1966. Ustilago nuda in Cappelle-Desprez winter wheat. Trans. Br. Mycol. Soc.49: 437-44t.

Edgington LV, Walton GS, Miller PM, 1966. Fungicides selective for Basidiomycetes. Science 153, 307-8.

GORTER, G. J. M. A. 1964. Loose smut of wheat in South Africa: Pathogenic races and reaction of locally grown cultivars. S. Afr. J. Agric. Sci.7:57-64.

Gorter, G.J.A.M. 1964a. Loose smut of wheat in South Africa: pathogenic races and reaction of locally grown cultivars. S. African J. Agric. Sci. 7:57-64.

Grevel, F.K. 1930. Untersuchungen ueber das Vorhandensein biologischer Rassen des Flugbrandes des Weizens (Ustilago tritici). Phytopathol. Z. 2:209-234.

Hanna, W.F. 1938. The association of bunt with loose smut and ergot. Phytopathology 28:142-146.

HEINRICH, I. 1973. (The physiological differentiation of the loose smut of wheat Ustilago tritici (Pers.) Rostr. occurring in Poland.) Acta Agrar. Silvest. Ser. Agrar. XIII: 53-66.

Hendry, G.W., and H.N. Hansen. 1934. The antiquity of Puccinia graminis and Ustilago tritici in California. Phytopathology 24:1313-1314.

http://www.uky.edu/Ag/IPM/scoutinfo/wheat/disease/disl ist.htm).

Humphrey, H.B., and V.F. Tapke. 1925. The loose smut of rye (Ustilago tritici). Phytopathology 15:598-606.

Kanehira, T., and M. Shinohara. 1986. Comparison of electrophoretic patterns of enzymes from Ustilago spp. parasitic on barley, wheat and oats. Ann. Phytopath. Soc. Japan 52:660-668.

Kehri, H.K and Chandra, S. (1991). Antagonism of Trichoderma viride to Macrophomina phaeolina in the control of dry root rot of mung. Indian Phytopathology 44: 60-63.

Kellerman, W.A., and W.T. Swingle. 1889. Report on the loose smuts of cereals. Kansas Agric. Exp. Sta. Manhattan Ann. Rpt., pp. 213-288.

Kim, W.K., R. Rohringer, and J. Nielsen. 1984. Comparison of polypeptides in Ustilago spp. pathogenic on wheat, barley and oats: a chemotaxonomic study. Can. J. Bot. 62:1431-1437.

Knox, R. \& Menzies, J. (2012). Resistance in wheat to loose smut. In: Sharma, I. (Ed.) Disease resistance in wheat. pp. 160-189 CAB International. ISBN 1845938186.

Krivchenko, 1970. Physiological specialization and distribution of races of Ustilago tritici (Pers.) Jens. in the USSR. Mikol. Fitopatol. V. 1. (4): 130-138. 
M.M.S. Malik, C.C.V. Batts; 1960. Transactions of the British Mycological Society. 43, 117.125.

Martin R.A, Edgington IV, 1980. Effect of temperature on efficiency of triadimenol and fenapanil to control loose smut of barley. Canadian Journal of Plant Pathology2, 201-4.

Mascarenhas, F. O. F. and DA Silva. A. R. 1954. Pesquisas de fontes de resistencia ao Ustilago tritici (Pers.) Rostr. Relat6rio de trabalhos realizados no Instituto Agronomico do Sul. Pelotas.

Matanguihan, G.J., Murphy, K.M. \& Jones, S. (2011). Control of common bunt in organic wheat. Plant Disease 95(2), 92-103.

Mathur, S.B. \& Cunfer, B.M. (1993). Seed-borne Diseases and Seed Health Testing of Wheat: Institute of Seed Pathology for Developing Countries. Danish Government. ABC Grafic. Frederiksberg, Denmark. ISBN 87 70263299.

MITOV, N. 1958. (Resistance of some Bulgarian and foreign wheat varieties to six groups of physiologic races of loose smut - [Jstilago tritici (Pers. I Jensen). Bull. Plant Prot., Sofia 7: 2t-33.

Mukhopadhyay, A.N., Shrestha, S.M. and Mukherjee, P.K. (1992). Biological seed treatment for control of soilborne plant pathogens. FAD Plant Proto Bull. 40: 21-30.

Murray, T.D., Parry, D.W. \& Cattlin, N.D. (2009). Diseases of Small Grain Cereal Crops: A colour Handbook. London, UK: Manson Publishing.

Neergaard, P. (1986). Screening for plant health. Annual review of phytopathology 24(1), 1-17.

Nielsen, J. \& Thomas, P. (1996). Loose Smut. In: Wilcoxson, R.D. \& Saari, E.E. (Eds.) Bunt and Smut Diseases of Wheat: Concepts and Methods of Disease Management.Mexico, D.F.: CIMMYT.

Nielsen, J. 1973. Reaction of Triticale and spring rye to loose smut of wheat. Can. J. Plant Sci. 53:749-753.

Nielsen, J. 1978. Host range of the smut species Ustilago nuda and Ustilago tritici in the tribe Triticeae. Can. J. Bot. 56:901-915.

Nielsen, J. 1983. Spring wheats immune or highly resistant to Ustilago tritici. Plant Dis. 67:860 863.

Nielsen, J. 1985. Ustilago spp. pathogenic on Aegilops. II. Ustilago tritici. Can. J. Bot. 63:765 771.

Nielsen, J. 1987a. Races of Ustilago tritici and techniques for their study. Can. J. Plant Path. 9:91-105.

Nielsen, J. 1987b. Reaction of Hordeum species to the smut fungi Ustilago nuda and U. tritici. Can. J. Bot. 65:2024-2027.

Nielsen, J., and P.L. Dyck. 1988. Three improved differential hosts to identify races of Ustilagotritici. Can. J. Plant Path. 10:327-331.

Nielsen, J., and V. Tikhomirov. 1993. Races of Ustilago tritici identified in field collections from eastern Siberia using Canadian and Soviet differentials. Can. J. Plant Path. 15:193-200.

Oort, A. J. P. 1944. Onderzoekingen over stuifbrand II. Overgevoeligheid van tarwe voor stuifbrand (Ustilago tritici). With a summary: Hypersensitiveness of wheat to loose smut. Tijdschr. Plantenz. 50: 73- 106.

Oort, A. J. P. 1963. A gene-for-gene relationship in the Triticum-Ustilago system, and some remarks on hostpathogen combinations in general: Neth. J. Plant Pathol. 69:104- 109.

Oort, A.J.P. 1947. Specialization of loose smut of wheat-a problem for the breeder. Tijdschr. Plantenz. 53:2543.

P. Eibel, G.A. Wolf, E. Koch; 2005. European Journal of Plant Pathology: 111, 113.124.

Pearce, D. (1998). PCR as a Tool for the Investigation of Seed-borne Diseases. In: Bridge, P.D., Arora, D.K., Reddy, C.A. \& Elander, R.P. (Eds.) Applications of PCR inMycology. pp. 309-324 CAB International. ISBN 0851992331.

Pett, B., Muminjanov, H. \& Morgounov, A. (2006). Monitoring of Wheat Diseases and Pests in Tajikistan in 2004. Agromeridian, Theoretical and Applied Agricultural ResearchJournal 1(2), 43-48.

Piekenbrock, P. 1927. Untersuchungen ueber das Verhalten des Ustilago tritici an Sorten und Kreuzungen. Kuehn Archiv. 15:411-456.

KnoxR.E., M.R.Fernandez, A.L.Brule-Babel, R.M.Depauw; 1990. Can J.Plant Pathol., 21, 174-180.

SammourR.H., M.A. Hamoud, A.S. Haidar; 1991. Cytologia: 56, 289-291.

R.H. Sammour; 1991. Folia Geobotanica, Phytotaxonomica: 26, 95-100.

R.H. Sammour; 1994. Feddes Repertorium: 105, 191- 196.

R.H.Sammour, A.A.Mustafa, S.Bader, W.Tahr; 2007. Acta agriculturae Slovennica, 88, 33-43, 77.

Radulescu, E. 1935. Untersuchungen ijber die physiologische Spezialisierung bei Flugbrand des Weizens, Ustilago rrillcl (Pers.) Jens. Phytopathol. Z. 8: 253-258.

Raguchander, T., Rajappan, K. and Samiappan, R. (1997). Evaluating methods of application of bio control agents in the control of Mungbean root rot. IndianPhytopathology 50: 229-234.

Rewal, H.S., and J.S. Jhooty. 1986a. Physiologic specialization of loose smut of wheat in the Punjab State of India. Plant Dis. 70:228-230.

Richardson, M.J. (1996). Seed mycology - centenary review. Mycological Research 100(4), 385392.

S. Badr, A.A. Mustafa, W. Tahr, R.H. Sammour; 2009.Cytologia: 74, 101-111.

Saari, E.E., Mamluk, O.F. \& Burnett, P.A. (1996). Wheat Bunts and Smuts. In: Wilcoxson, R.D. \& Saari, E.E. 
(Eds.) Bunt and Smut Diseases of Wheat: Concepts and Methods ofDisease Management. Mexico, D.F.: CIMMYT.

Sankar, P. and Jeyarajan, R. (1996). Seed treatment for biological control of Macrophomina phaseolina in Sesamum. Indian Phytopathology 49: 148-151.

Sharma, S.K., Verma, B.R. and Sharma, B.K. (1999). Biocontrol of Sclerotinia sclerotiorum causing stem rot of chickpea. Indian Phytopathology 52: 44-46.

Shinohara, M. 1976. Behaviour of Ustilago nuda (Jens.) Rostr. and U. tritici (Pers.) Rostr. in theirhost tissues. Rev. Plant Prot. Res. 9:124-142.

Silva, A. R. DA. 1951. Melhoramento Genetico das Plantas Cultivadas para ResistCncia d Doengas Parasit6rias: Principios Fundamentais e sua Aplicagdo aos Trabalhos de Melhoramento deTrigo. Bol. Tec.Inst. Agron. Sul. No.4. W. Popp; 1951. Phytopathology, 41, 261-275.

Simon, M. and Croisier, L. 1959. Apparition d'une nouvelle race de charbon du bl6 en France. C.R. Acad. Agric. Fr. 45: 790-792. (Abstr. in Rev. Appl. Mycol. 39: 565, 1960). Soc. 41:115-125.

T.D. Murray, D.W. Parry and N.D. Cattlin, 2009. Diseases of Small Grain Cereal Crops, Manson Publishing Ltd.

Taylor, E., Bates, J. \& Jaccoud, D. (2006). Diagnosis of Seedborne Pathogens. In: Basra, A.S.(Ed.) Handbook of Seed Science and Technology. pp. 649-676 Food Product Press. ISBN 1560223146.

Tiemann, A. 1925. Untersuchungen ueber die Empfaenglichkeit des Sommerweizens fuer Ustilago tritici und den Einfluss der aeusseren Bedingungen dieser Krankheit. Kuehn Archiv 9:405-467.

Vánky, K. 1994. European smut fungi. Gustav Fischer Verlag, New York, 570 pp.

Von Schmeling B, Kulka M, 1966. Systemic fungicidal activity of, 1, 4-oxathiin derivatives. Science 152, 65960.

Rennie W.J.; 1990. Working Sheet No. 25. In: ISTA Handbook on Seed Health Testing (Section 2: Working Sheets), International Seed Testing Association, Zurich, Switzerland.

Wilcoxson, R.D., and E.E. Saari, eds. 1996. Bunt and Smut Diseases of Wheat: Concepts and Methods of Disease Management. Mexico, D.F.: CIMMYT.

Zillinsky, F.J. (1983). Common Diseases of Small Grain Cereals: A Guide to Identification. Mexico, D.F.: International Maize and Wheat Improvement Center (CIMMYT). ISBN 9780318212654. 